\title{
The Use of Simile in Emily Brontë's Wuthering Heights
}

\author{
Jemma Militonyan \\ Yerevan State University Ijevan Branch
}

\begin{abstract}
Figures of speech are imaginative tools in both literature and ordinary communication used for explaining speech beyond its usual usage. Emily Brontë's Wuthering Heights (1847) - the only novel written by this writer differs from many other literary works due to its style, its particular use of language and figures of speech. The literary tool and figure of speech we have illustrated in the present paper is the simile. Emily Brontë uses simile as a means both to creatively and purposefully convey her thoughts and ideas to the reader and to impact him/her. The literary analysis shows that the simile is also an excellent device for the author to make an unusual thing seem more familiar or a familiar thing seem more unique. Through simile the reader may imagine vividly the fictive world of Emily Brontë's Wuthering Heights.
\end{abstract}

Key words: simile, comparison, metaphor, functions of simile, imaginative tools, structural design.

\section{Introduction}

Emily Brontë's Wuthering Heights (1847) has aroused much controversy based on themes, style and techniques. The novel received neither critical praise nor any local popularity during its initial publication. The Victorian society would not accept the violent characters and harsh realities of Wuthering Heights, so it had been deemed as coarse, immoral, brutal, disagreeable and diabolical (Anonymous 1848). The reading public has changed substantially since 1847, and now both critical and popular opinion praise this singular work of fiction by Emily Brontë. The subsequent audiences are both more understanding and accepting the use of unsavory aspects of human life in literature. Modern critics 
speak highly of the strength of the novel's structure and on Emily Brontë's dynamic and disciplined handling of language. Stylistically, much ahead of her time, Brontë culled a form best suited to articulate her subject and ideas effectively. In fact, Mark Schorer (1949) wrote a praising introduction to Wuthering Heights presuming it as one of the most carefully constructed novels in literature. The novel, as an effective medium for the criticism and interpretation of life, comes into existence through the creativity of the writer. The literary text is an artifice; a work of verbal art, and the readers come in contact with the fictional world of the novel through its language. In fact, many contemporary critics praising Brontë's style, imagery, and word choice, contend that Wuthering Heights is actually poetry masquerading as prose.

\section{Simile, Comparison, Metaphor in Wuthering Heights}

Figures of speech are imaginative tools in both literature and ordinary communications used for explaining speech beyond its usual usage. Figurative language constitutes the cornerstone of the literariness or ornamental nature of literary language, as it enables the writer to exploit and manipulate the latent potentials of language, in various ways, for specific stylistic effects (Fadaee 2011:21). In her novel Brontë makes a wide use of such figures of speech as metaphor, simile, personification, imagery, irony, hyperbole, etc.

The word simile is derived from the Latin word simile, meaning resemblance and likenesses. Technically, simile is the comparison of two objects with some similarities. It is stated that "Simile is fundamentally a figure of speech requiring overt reference to source and target entities, and an explicit construction connecting them" (Gibbs 1994:40).

Here are some more definitions of simile:

'"The intensification of some one feature of the concept in question is realized in a device called simile" (Galperin 1981:152).

"Like metaphor, it [the simile] is a semantic figure, a mental process playing a central role in the way we think and talk about the world, which often associates different spheres" (Bredin 1998:68). 
Most definitions of simile describe it as involving "an explicit comparison between two things or actions" - signalled, in the majority of cases - by the presence of like (Cruse 2006:165).

The aim of using a simile is to attain a more figurative or graphic characterization of one of the objects compared. An indispensable condition for the creation of a simile is the likeness of one feature belonging to both of the objects while other features may be entirely different. At the same time this common feature is permanently characteristic of only one of the objects compared. We should not confuse ordinary comparison and simile as they represent two diverse processes. Galperin (1981:152) states that "comparison means weighing two objects belonging to one class of things with the purpose of establishing the degree of their sameness or difference."

The simile expresses complex analogical conceptualizations between entities of two different domains while the comparison focuses on the same domain. Along with the simile, we can find examples of ordinary comparisons in the mentioned novel.

His books are not as nice as mine.

He imagined himself to be as accomplished as Linton.

He was as quick and as intelligent a child as ever you were.

Only, Catherine, do me this justice: believe that if I might be as sweet, and as kind, and as good as you are, I would be as willingly, and more so, than as happy and as healthy.

(pp. 95, 105, 105, 107)

The comparison takes into consideration all the properties of the two objects, focusing on the one that is compared. The simile differs from the ordinary comparison as the subject matter, i.e., the target object in the simile is characterized through its comparison with another, ontologically heterogeneous object. The result is the creation of a new subjective image, different from the original. The simile excludes all the properties of the compared objects except the one which is common to them (Miller 1993:373). 
The simile forcibly sets one object against another regardless of the fact that they may be completely alien to each other.

And, without our being aware of it, the simile gives rise to a new understanding of the characterizing object - as well as of the object characterized. The comparison in a simile is formally expressed by words like as, as if, as though, like, seem.

[...] and by a range of gaunt thorns all stretching their limbs one way, as if craving alms of the sun.

[...] he broke out as I entered, turning to his daughter-in-low, and employing an epithet as harmless as duck, or sheep.

Catherine's face was just like the landscapes-shadows and sunshine flitting over it in rapid succession [...].

$$
\text { (pp. } 4,14,111)
$$

Like in the simile, in the metaphor two different phenomena (things, events, ideas, actions) are simultaneously brought to mind by the imposition of some or all of the inherent properties of one object on the other which by nature is deprived of these properties. Such an imposition generally results in the creation of metaphor. The creator of the metaphor finds in the two corresponding objects certain features which to his eye have something in common (Galperin 1981:127). The comparison, however, is not expresses through the like or as (as in the case of the simile).

The most general description is that metaphor is an expression with two conceptual domains (knowledge fields) - where one is understood in terms of the other (Gibbs 1994). The two concepts are referred to as source and target, where the source is the domain where the actual statement is generated, and target is the domain that will be used to explain the statement. Often, the two domains even help to explain each other (Fauconnier 1995). Encyclopaedia Britannica (Metaphor 2017) puts it as follows: "metaphor [is a] figure of speech that implies comparison between two unlike entities, as distinguished from simile, an explicit comparison signalled by the words like or as." Metaphors have a way of activating previous experiences and associations. At a first glance 
they can seem ambiguous and paradoxical, but in practice they can explain complex concepts both quicker and more accurate than a more literal explanation. Both the simile and the metaphor are figures of speech, and both operate by comparing the thing with something else in a figurative (not literal) way. This is why the simile and the metaphor can be somehow confusing.

It is sometimes believed that the difference between the simile and the metaphor comes down to a word. Similes use the words like or as to compare things while metaphors, in contrast, directly state a comparison. But, actually, the two imply different aspects of language. A simile retains some irresolvable difference which means one can never fully substitute for the other. On the other hand, a metaphor actually is a substitution. Thus, it can be stated that if the simile is an approximation, then the metaphor is an equation itself. The simile, being an approximation, cannot be extended, substituted, or reversed. But the metaphor, being an equation, can be reversed, extended, and substituted by other metaphors.

We have to remember that metaphors and similes are not paraphrases of one another. They can, of course, function as paraphrases of one another in a usual or most frequent case, when a metaphor and a simile yield comparable interpretations. But this most usual or frequent case is, paradoxically, a special case: it is not a universal property of the metaphors and the respective simile (Glukcksberg 2006:376).

Here are some vivid examples of metaphorical usages from the Wuthering Heights:

It was not the thorn bending to the honeysuckles, but the honeysuckles embracing the thorn.

[...] the stab of a knife could not inflict a worse pang than he suffered at seeing his lady vexed.

[...] one thin, blue wreath, curling from the kitchen chimney.

(pp. 40, 40,127) 


\section{The Functions of the Simile}

According to Fromilhague (1995:88-94), the simile has various functions: first, it serves as a means of communicating concisely and efficiently. It is one of the sets of linguistic devices which extends the linguistic resources available. Secondly, it can function as a cognitive tool for thought in that it enables us to think about the world of the novel in alternative ways. In discourse, the simile can also fulfill more specific functions depending on the textual genre in which it occurs. In scientific texts, for example, the simile and analogical reasoning play an important role.

A simile usually consists of three components: (a) what is compared (the subject of the simile); (b) with what the comparison is made (the object of the simile) and (c) the basis of the comparison (e.g. subj. basis obj. She trembled like a reed.).

The common feature between two ideas in a simile is most frequently expressed by an adjective:

[...] when glare of white letters started from dark, as vivid as specters.

[...] and his face as white as the wall behind him.

[...] took an opportunity of escaping into the free air, now clear, and still, and cold as impalpable ice.

[...] her eyes sparkled as bright as diamonds.

They both promised to grow up as rude as savages.

[...] and Linton's is as different as a moonbeam from lightning, or frost from fire.

[...] for the space of half a year, the gunpowder lay as harmless as sand.

$$
\text { (pp. 10, 13, 15, 20, 21, 35, 40) }
$$

We can come across many other examples in the Wuthering Heights where Emily Brontë uses different animal similes for a more imaginative 
characterization of a phenomenon, and represents features typical of animals to characterize people.

[...] who obeyed her like a dog.

He's just like a dog, is he not, Ellen.

[...] pulling me back by the skin of my neck, like a dog.

[...] he gnashed at me and foamed like a mad dog.

I'd go stretch myself over her grave and die like a faithful dog.

[...] I noticed he breathed as fast as a cat.

We were quarrelling like cats about you.

[...] turning to his daughter-in-law, and employing an epithet as harmless as duck, or sheep.

[...] I adjourned to my study, feeble as kitten [...].

[...] he was as uncomplaining as a lamb...

Her cousin had shrunk into a corner of the settle, as quiet as a mouse [...].

We all kept as mute as mice a full half hour.

[...] and on my giving chase ran like a mouse over and under and behind the furniture.

[...] she could be as soft and mild as a dove...

[...] and he would crush you like a sparrow's egg.

Cathy, this lamb of yours threatens like a bull!

[...] asked the hermit, glaring like a hungry wolf.

[...] for we heard him sporting like a horse...

I confess it with shame-shrunk icily into myself, like a snail. (pp. 110, 130, 32, 69, 75, 136, 46, 14, 15, 18, 113, 20, 83, 80, 45, $50,59,80,4)$

Similes may suggest analogies in the character of actions performed. In this case the two members of the structural design of the simile will resemble each other through the actions they perform. 
She turned upon me as a mouse might turn if anyone attempted to assist him in counting his gold.

My love for Linton is like the foliage in the woods: time will change it, I'm well aware, as winter changes the trees.

Heathcliff would as soon lift a finger at you as the king would march his army against a colony of mice.

He might as well plant an oak in a flower-pot, and expect it to thrive, as imagine he can restore her to vigour in the soil of his shallow cares?

[...] his frame shivering, not as one shivers with chill or weakness, but as a tight-stretched cord vibrates-a strong thrilling, rather than trembling.

[...] and she only remained, heaving like a sea after a high wind...

[...] they've gone through and through me, like wine through water, and altered the colour of my mind.

(pp. 7, 36, 50, 66, 137, 5, 35)

Emily Brontë uses the words devil, satan and death for descriptions and evaluations of some notions (mainly implying certain negative coloring).

[...] though it's as dark almost as if it came from the devil.

[...] and the whole of that time all round has been as still as death

Well, I won't repeat my offer of a wife: it is as bad as offering Satan a lost soul.

His young and fair features were almost as deathlike as those of the form beside him, and almost as fixed...

[...] but lurk glinting under them, like devil's spies...

Lonely, like the devil, and envious like him.

$$
\text { (pp. 17, 40, 49, 70, 25, 120) }
$$




\section{Conclusion}

Similes elaborate, hopefully in a way that makes the writing more understandable or relatable. Using similes attracts the attention and appeals directly to the senses of readers creating a picture in their minds which will make them experience what is being described in a more vivid way.

The creativity of fiction depends to a large extent on the novelist's artistic manipulation of the resources of language in order to attain certain aesthetic effect and we can see that Emily Brontë was a master of that manipulation and asserts similarity as two different notions presupposing dissimilarity.

\section{References:}

1. Anonymous (1848) Douglas Jerrold's Weekly Newspaper, Jan.15, London.

2. Bredin, H. (1998) Comparisons and Simile. // Lingua, 105, pp. 67-78.

3. Cruse, D.A. (2006) A Glossary of Semantics and Pragmatics. Edinburgh: Edinburgh University Press.

4. Fadaee, E. (2011) Symbols, Metaphors and Similes in Literature: A Case Study of Animal Farm. // Journal of English and Literature Vol. 2(2), pp. 19-27.

5. Fauconnier, G. (1995) Cognitive Mappings in Semantics. // Ling. 554.351, University of New Mexico, Summer Program.

6. Fromilhague, C. (1995) Les Figures de Style. Paris: Nathan Université.

7. Galperin, I.R. (1981) Stylistics. M.: Moscow Higher School.

8. Gibbs, R.W. (1994) The Poetics of Mind. UK, Cambridge: CUP.

9. Glucksberg, S. \& Haught, C. (2006) On the Relation Between Metaphor and Simile: When Comparison Fails. // Mind and Language, 21 (3), pp. 360-378.

10. Metaphor. (Copyright 2017) // Encyclopædia Britannica, Inc. Available at: $<$ https://www.britannica.com/art/metaphor> [Accessed July 2017].

11. Miller, G. (1993) Images and Models, Similes and Metaphor. // Metaphor and Thought. Cambridge: CUP, pp. 357-400.

12. Schorer, M. (1949) Fiction and the Matrix of Anology. // The Kenyon Review. Vol. 11 (4), pp. 539-560. 


\section{Source of Data:}

Brontë, E. (1992) Wuthering Heights. London: Wordswoth Editions.

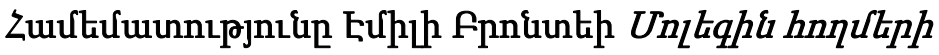

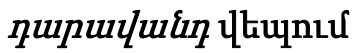

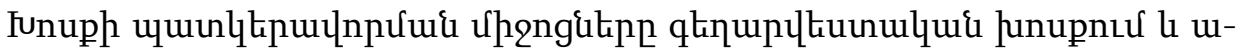

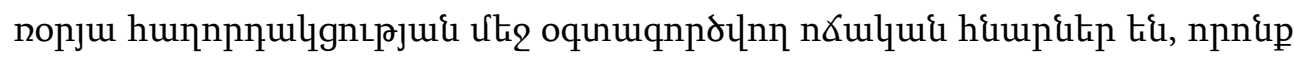

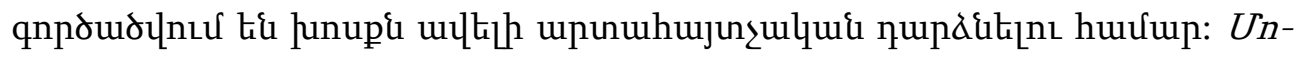

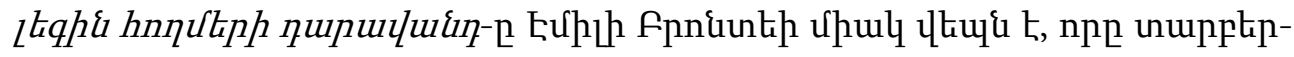

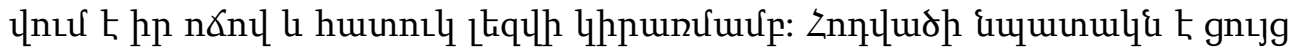

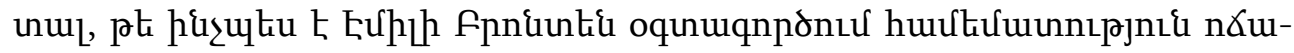

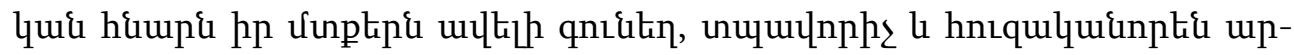

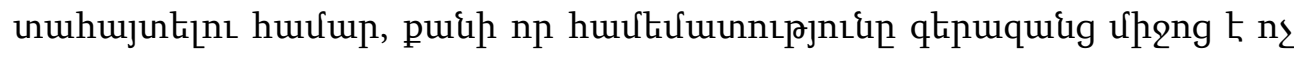

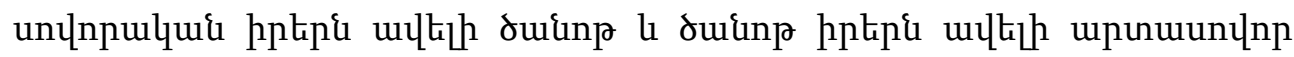

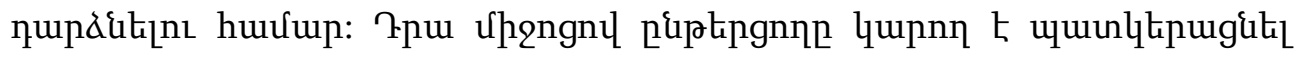
qpulqui kplh tpliulqujulquis urłauphn: 